\title{
Determining the humus formation index of forest soils of the Vologda Region
}

\author{
Yliya Duryagina ${ }^{1}$, Ludmila Voropay $^{1}$, Svetlana Hamitova ${ }^{1,2^{*}}$, Ilfir Galiullin ${ }^{3}$ and Olga Kuztetsova ${ }^{1}$ \\ ${ }^{1}$ Vologda State University, 15, Lenina Str., Vologda, 160000, Russia \\ ${ }^{2}$ All-Russian Research Institute of Phytopathology, 5, Institute, Odintsovo district, Bolshie Vyazemy, 143050, Russia \\ ${ }^{3}$ Faculty of Forestry and Ecology, Kazan State Agrarian University, 25, K. Marx Str., Kazan, 420015, Russia
}

\begin{abstract}
The processes of soil formation and its fertility are influenced by various factors, including concentration of various elements and substances. In the course of this study, soil samples were taken from different districts of the Vologda Oblast. Chemical composition of the samples and the humus formation index were determined. Based on the results obtained, the dependences of the humus formation index on the content of some cations and anions were established.
\end{abstract}

\section{Introduction}

Currently, in the Vologda Region, work is underway to assess the quality of soils, which are not agricultural land at present and are located in the most risky areas, not far from landfills, highways, construction sites and industrial enterprises. As part of this work, the Department of Chemistry and Biology of the Vologda State University is conducting research on the assessment of the chemical composition of the soil and on the effect of the chemical composition on the processes of humus formation. Analysis of the literature shows that mainly studies of soils are carried out for the content of organic components and iron, however, the processes of humus formation and the influence of heavy metals (for example, iron and manganese) on them, which catalyze and inhibit Red-Ox processes occurring with organic compounds. Based on this, in this work, an attempt is made to experimentally establish the dependence of the processes of humus formation on the content of iron and manganese.

It is known that soils, like living organisms, contain almost all the elements found in the periodic system of D. Mendeleev, with the exception of artificially obtained transuranic elements. The elemental or gross composition of the soil is the most important characteristic by which its genesis and fertility are determined. The results also influence selection and development of methods for the chemical analysis of soil formation. According to the gross composition, humusaccumulative horizons are also determined, which are characterized by an increased content of biogenic elements carbon, phosphorus, nitrogen [1-3]. These horizons are among the most fertile zones.

Chemical elements, even with their low content, participate in the processes of soil formation, in the biochemical processes of accumulation, transformation, transfer of compounds in ecosystems, and also stimulate the activity of microorganisms. For example, manganese is involved in the formation of a humic substance. The rate of the reaction of clay formation, the synthesis of colloids, illuviation processes, and hydrogenic accumulation also depend on its amount.

The gross composition of soils also characterizes the mechanism and types of the reaction of soil formation, including the processes of humus formation. It is known that soil fertility, the stability of the water-salt balance, and the buffer capacity of soil aggregates under conditions of erosion and deflation depend on the content and composition of humus. Humus has a complex heterogeneous composition and includes organic compounds belonging to different classes and passed certain stages of soil formation: carbohydrates, proteids, lignin, lipids, amino acids, poly- and monophenols, sugars, heterocycles, humic acids and their derivatives, fatty acids [4].

It should be noted that most chemical elements in soils are bound in humus, including metals. Metal cations of the entire organic component of the soil humus form organo-mineral complexes, in which complexing agents occupy different positions. The nature of the connection between humic substances and metal cations is not fully understood and depends on many factors, including the ability of metals to form humino-coordination complexes at different $\mathrm{pH}$ values, where metal cations are in different oxidation states.

An important role in soil formation processes is assigned to metals - iron and manganese, participating in Red-Ox processes due to their ability to easily transform into compounds with different oxidation states. The stability of different forms of iron and manganese in soils depends on the $\mathrm{pH}$ values, the product of solubility, and the value of the standard electrode potentials of metal derivatives.

\footnotetext{
* Corresponding author: xamitowa.sveta@yandex.ru
} 
Depending on the stage of humus formation, the content of iron and manganese as complexing agent changes. For example, iron content in soils varies from 0.5 to $6 \%$, making this element the fourth most common element in the soil and thus a macroelement. Manganese is included in the transition group of trace elements, and its content ranges from 0,01 to $0,3 \%$.

Allocation of elements in bound form in soils also depends on the soil horizon, the chemical composition of the earth's shell, climate, humidity, and on their geochemical classification. According to the geochemical classification, iron and manganese belong to chalcophiles, siderophiles, and biophiles. According to the peculiarities of their migration in soils, these elements are mobile in a reducing gley environment. According to the degree of biophilicity, which is characterized by the ability of plants to selectively absorb chemical elements, iron and manganese are classified as elements with low biophilicity. Biophilicity, in turn, also depends on the oxidation state in which these metals are bound with organic substances (humic acids). Iron can be found in oxidation states +2 and +3 ; manganese - from +2 to +7 . The most stable are organometallic complexes in which iron and manganese are in reduced forms. According to the total content of the reduced stable forms of iron and manganese, the stages of the humus formation process are determined, and these characteristics largely depend on the $\mathrm{pH}$ value. Knowing the $\mathrm{pH}$ value, one can correlate the presence of reduced and oxidized forms of metals and determine their participation in the processes of humus formation. For example, at a $\mathrm{pH}$ value of 2 to 6 , iron exists in forms $\mathrm{Fe}^{+3}, \mathrm{Fe}(\mathrm{OH})^{+2}, \mathrm{Fe}(\mathrm{OH})_{2}{ }^{+}$, and also forms salts $\mathrm{FeCO}_{3}$, $\mathrm{FeH}_{2} \mathrm{PO}_{4}{ }^{+}, \mathrm{Fe}\left(\mathrm{H}_{2} \mathrm{PO}_{4}\right)_{2}$. In the $\mathrm{pH}$ range from 6 to 11 , $\mathrm{Fe}^{+3}$ is in the form of iron hydroxides $\mathrm{Fe}(\mathrm{OH})_{4}{ }^{-1}$, $\mathrm{Fe}(\mathrm{OH})_{2}, \mathrm{Fe}(\mathrm{OH})_{4}{ }^{2-}$.

Manganese, depending on the $\mathrm{pH}$ value in an acidic medium, exists in forms $\mathrm{Mn}^{+4}, \mathrm{Mn}(\mathrm{OH})_{3}{ }^{-1}, \mathrm{Mn}^{+3}$, $\mathrm{Mn}(\mathrm{OH})^{+2}, \mathrm{Mn}_{2}(\mathrm{OH})^{+3}$, in an alkaline environment manganese most often forms complexes with oxidation states +6 and +4 . Such compounds are less stable to hydrolysis processes, and suchlike complexes are easily hydrolyzed in neutral conditions $[5,6]$.

\section{Materials and methods}

In this regard, the goal was set to establish the dependence of the value of the soil fertility index on the content of iron and manganese, which are in different oxidation states and are part of complexes with humic acids.

To achieve this goal, the following tasks were solved:

1. Using modern instrumental research methods, determine the chemical composition of soil samples taken from different areas of the Vologda region (Ustyuzhensky, Babaevsky, Cherepovetsky, Vologda areas).

2. Define the content of organic fractions and estimate the fertility index.

3. Examine soil samples for the content of iron and manganese compounds.
4. Analyze the obtained results and ascertain the correlation between the content of iron and manganese and the fertility index.

During the course of the work, the following physicochemical methods of analysis were used: titrimetric, gravimetric, potentiometric, fluorimetric and photometric methods.

The object of the research is soil samples from the Vologda region.

The subject of the research is to establish the correlation between the soil fertility index and the content of iron and manganese.

Figure 1 shows a schematic map of soil sampling sites.

The numbers on the map represent the areas with the indication of the prevailing types of forests: 1 Ustyuzhensky district, blueberry pine forest; 2 - Babaevsky district, blueberry pine forest; 3 - Babaevsky district, Borisosvoudskoe, blueberry forest; 4 - Borisosuvodskoe, mixed forest; 5 - Vologda district, mixed forest; 6 Cherepovets district, mixed-deciduous forest.

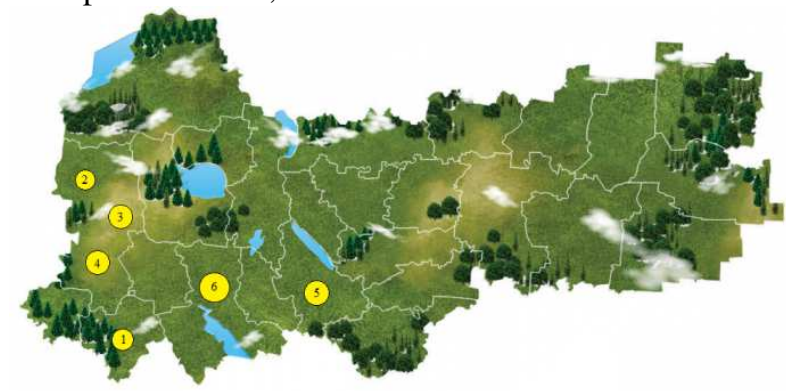

Fig. 1. Soil sampling sites

\section{Results}

Newly-taken soil samples were subjected to fractionation by the sieve analysis method. Soil samples were sieved through sieves with a hole diameter of $1.0 ; 1.2 ; 1.5 ; 1.7$; $2.0 ; 2.5 ; 3.0 \mathrm{~mm}$ and separated from remains of plants, mechanical inclusions. The fractional composition was determined gravimetrically. The research results are presented in table 1.

The results of the research showed that for samples No. 2, No. 4, No. 5 and No. 6, large fractions with a diameter $>3 \mathrm{~mm}$ prevail. For samples No. 1 and No. 3, fractions with a diameter $<1$ prevail.

While determining the humus content in soils, the samples were subjected to heat treatment at a temperature of $800^{\circ} \mathrm{C}$. At this temperature, the processes of decomposition of organic compounds and oxidation of inorganic impurities occur. Samples of soil weighing $10 \mathrm{~g}$ were taken and placed in crucibles; after calcination, the ash residue was weighed. The content of organic fractions was determined from the difference between the masses of the soil before combustion and the ash residue. The humus formation index was calculated using the formula (1):

$$
I=m_{\text {hum }} / m_{\text {soil }}
$$

I - humus formation index;

$\mathrm{m}_{\text {hum }}$ - humus mass, g;

$\mathrm{m}_{\text {soil- }}$ soil mass before calcination, $\mathrm{g}$. 
Table 1. Soil fractional composition

\begin{tabular}{|c|c|c|c|c|c|c|c|c|c|c|c|}
\hline \multirow{2}{*}{$№$} & Sampling site & \multicolumn{7}{|c|}{ Fractional composition in \% by diameters (D) of sieve holes, mm } \\
\cline { 3 - 11 } & & $>3$ & $3-2.5$ & $2.5-2$ & $2-1.7$ & $1.7-1.5$ & $1.5-1.2$ & $1.2-1$ & $<1$ & Losses \\
\hline 1 & $\begin{array}{c}\text { Ustyuzhensky district, } \\
\text { blueberry pine forest }\end{array}$ & 16.9 & 8.9 & 0.019 & 0.028 & 1.16 & 2.39 & 5.44 & 65.1 & 0.063 \\
\hline 2 & $\begin{array}{c}\text { Babaevsky district, } \\
\text { blueberry pine forest }\end{array}$ & 39.87 & 8.88 & 0.76 & 0.98 & 0.87 & 2.84 & 6.8 & 38.41 & 0.59 \\
\hline 3 & $\begin{array}{c}\text { Babaevsky district, } \\
\text { Borisosudskoe, blueberry } \\
\text { forest }\end{array}$ & 22.03 & 11.51 & 0.01 & 1.75 & 1.84 & 3.86 & 16.04 & 41.97 & 0.09 \\
\hline 4 & $\begin{array}{c}\text { Borisosudskoe, mixed } \\
\text { forest }\end{array}$ & 51.7 & 17.69 & 0.01 & 1.05 & 1.85 & 3.96 & 6.88 & 15.91 & 0.05 \\
\hline 5 & $\begin{array}{c}\text { Vologda district, mixed } \\
\text { forest }\end{array}$ & 38.23 & 26.34 & 0.74 & 1.97 & 2.41 & 5.58 & 10.89 & 13.26 & 0.58 \\
\hline 6 & $\begin{array}{c}\text { Cherepovets district, } \\
\text { mixed-deciduous forest }\end{array}$ & 23.52 & 21.55 & 0.94 & 2.49 & 2.8 & 8.1 & 18.02 & 21.95 & 0.63 \\
\hline
\end{tabular}

The research results are presented in table 2 .

Table 2. Humus formation index

\begin{tabular}{|c|c|c|}
\hline № & Sampling site & $\begin{array}{c}\text { Humus formation } \\
\text { index }\end{array}$ \\
\hline 1 & $\begin{array}{c}\text { Ustyuzhensky district, } \\
\text { blueberry pine forest }\end{array}$ & 0.031 \\
\hline 2 & $\begin{array}{c}\text { Babaevsky district, blueberry } \\
\text { pine forest }\end{array}$ & 0.0475 \\
\hline 3 & $\begin{array}{c}\text { Babaevsky district, } \\
\text { Borisosvoudskoe, blueberry } \\
\text { forest }\end{array}$ & 0.0715 \\
\hline 4 & Borisosuvodskoe, mixed forest & 0.0765 \\
\hline 5 & Vologda district, mixed forest & 0.089 \\
\hline 6 & $\begin{array}{c}\text { Cherepovets district, mixed- } \\
\text { deciduous forest }\end{array}$ & 0.136 \\
\hline
\end{tabular}

After determining the fractional composition, water extracts from the soil were prepared. For this, $100 \mathrm{~g}$ of soil was taken and placed in glasses, distilled water was heated to a temperature of $50-60{ }^{\circ} \mathrm{C}$ and poured into glasses with soil, the mixture was thoroughly mixed and left for 30 minutes for the transfer of water-soluble compounds to the extract. Then the solutions were filtered through ash-free filters. Further analysis was carried out with an water extract and the $\mathrm{pH}$ value was determined, the content of chloride ions, carbonate and bicarbonate ions, sulfate ions, nitrate and nitrite ions and phosphate ions, total hardness, the content of cations of ammonium, aluminum, manganese, iron, chromium and boron.

During the analysis, the following methods were used: RD 52.24.395-2017. Hardness of water. Methods for performing measurements by the titrimetric method with Trilon B [7]; GOST 4245-72. Drinking water. Methods for determination of chloride content [8]; GOST 31957-2012. Water. Methods for determination of alkalinity and mass concentration of carbonates and hydrocarbonates [9]; GOST 31940-2012. Drinking water. Methods for determination of sulfate content [10]; GOST 33045-2014 Water. Methods for the determination of nitrogen-containing substances [11]; PND F 14.1: 2: 4.181-02 (instead of 14.1: 2: 4.24-95) Methods for performing the mass concentration of aluminum in samples of natural, drinking and waste water by the fluorometric method using the Fluorat-02 liquid analyzer [12]; Method for determination of total iron content by colorimetric method with potassium thiocyanate; PND F 14.1: 2: 4.61-96 Methodology for measuring the mass concentration of manganese in natural and waste waters by the photometric method with ammonium persulfate [13]; PND F 14.1: 2: 4.36-95 Methods for measuring the mass concentration of boron in samples of natural, drinking and waste water by the fluorimetric method on the fluid analyzer "Fluorat-02" [14]; PND F 14.1: 2: 4.112-97 Methodology for measuring the mass concentration of phosphate ions in drinking, natural and waste waters by the photometric method with ammonium molybdate [15]; PND F 14.1: 2: 4.52-96 Methods for measuring the mass concentration of chromium ions in drinking, natural and waste waters by the photometric method with diphenylcarbazide [16].

The results of the research are presented in tables 3, 4 and 5.

Table 3. Anion content in water extracts, $\mathrm{pH}$ and hardness of extracts

\begin{tabular}{|c|c|c|c|c|c|c|c|}
\hline № & $\mathrm{pH}$ & 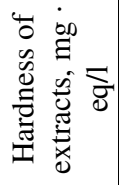 & 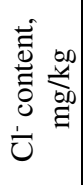 & 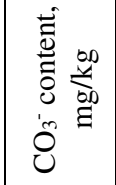 & 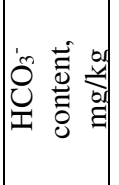 & 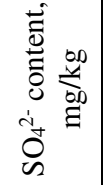 & 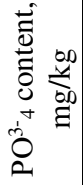 \\
\hline 1 & 5.05 & 0.367 & 94.3 & \multirow{6}{*}{ 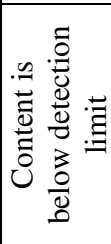 } & \begin{tabular}{|l|}
5288.7 \\
\end{tabular} & \multirow{6}{*}{ 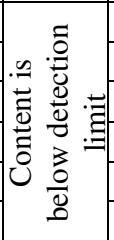 } & 2.03 \\
\hline 2 & 5.8 & 0.4 & 70.9 & & 4471.3 & & 4.0 \\
\hline 3 & 4.9 & 0.533 & 118.4 & & 3458.7 & & 4.9 \\
\hline 4 & 4.5 & 0.567 & 94.3 & & 3660.0 & & 12.3 \\
\hline 5 & 5.5 & 0.533 & 94.3 & & \begin{tabular}{|l|}
3251.3 \\
\end{tabular} & & 12.7 \\
\hline 6 & 5.1 & 0.767 & 94.3 & & $\mid 1628.7$ & & 9.6 \\
\hline
\end{tabular}

While analyzing the results, it should be taken into consideration that aqueous extracts contain not only water-soluble compounds, but also sparingly soluble ones, the content of which must correspond to the values of the solubility products. Taking these indicators into account, the indicators of hardness of water, the content of nitrite, nitrate ions, ammonium cations, chlorides and hydrocarbonates are most accurately determined. The quantitative content of sulfate, phosphate, carbonate 
ions, as well as cations of aluminum, iron, manganese does not correspond to the exact quantitative content of these compounds in soils.

Table 4. Content of nitrogen-containing compounds

\begin{tabular}{|c|c|c|c|}
\hline № & $\begin{array}{c}\mathrm{NO}_{3}{ }^{-} \text {content, } \\
\mathrm{mg} / \mathrm{kg}\end{array}$ & $\begin{array}{c}\mathrm{NO}_{2}^{-} \text {content, } \\
\mathrm{mg} / \mathrm{kg}\end{array}$ & $\begin{array}{c}\mathrm{NH}_{4}{ }^{+} \text {content, } \\
\mathrm{mg} / \mathrm{kg}\end{array}$ \\
\hline 1 & 39.57 & 3.13 & 6.68 \\
\hline 2 & 11.3 & 5.6 & 8.0 \\
\hline 3 & 65.95 & 5.56 & 9.58 \\
\hline 4 & 79.15 & 5.21 & 10.2 \\
\hline 5 & 3.43 & 11.55 & 11.0 \\
\hline 6 & 1.77 & 15.55 & 12.73 \\
\hline
\end{tabular}

Table 5. Cation content

\begin{tabular}{|c|c|c|c|c|c|}
\hline № & $\begin{array}{c}\mathrm{Al} \\
\text { content, } \\
\mathrm{mg} / \mathrm{kg}\end{array}$ & $\begin{array}{c}\mathrm{Fe} \\
\text { content, } \\
\mathrm{mg} / \mathrm{kg}\end{array}$ & $\begin{array}{c}\mathrm{Mn} \\
\text { content, } \\
\mathrm{mg} / \mathrm{kg}\end{array}$ & $\begin{array}{c}\mathrm{Cr} \\
\text { content, } \\
\mathrm{mg} / \mathrm{kg}\end{array}$ & $\begin{array}{c}\text { Воб } \\
\text { content, } \\
\mathrm{mg} / \mathrm{kg}\end{array}$ \\
\hline 1 & 2.1 & 1.0 & 2.1 & \multirow{6}{*}{$\begin{array}{l}\text { Content is } \\
\text { below } \\
\text { detection } \\
\text { limit }\end{array}$} & 0.72 \\
\hline 2 & 1.6 & 1.06 & 1.2 & & 0.81 \\
\hline 3 & 1.06 & 1.2 & 0.62 & & 1.3 \\
\hline 4 & 0.76 & 3.6 & 0.62 & & 1.4 \\
\hline 5 & 0.44 & 3.8 & 0.41 & & 1.13 \\
\hline 6 & 0.22 & 3.8 & 0.41 & & 2.5 \\
\hline
\end{tabular}

Simultaneously with the chemical composition of the water extracts, the content of iron and manganese in the soils in a bound form was determined using a sulfuric acid solution as a solvent: a $0.1 \mathrm{~N}$ solution was used to determine the manganese content, and a $40 \%$ solution was used to determine iron. The research results are shown in Figure 2.

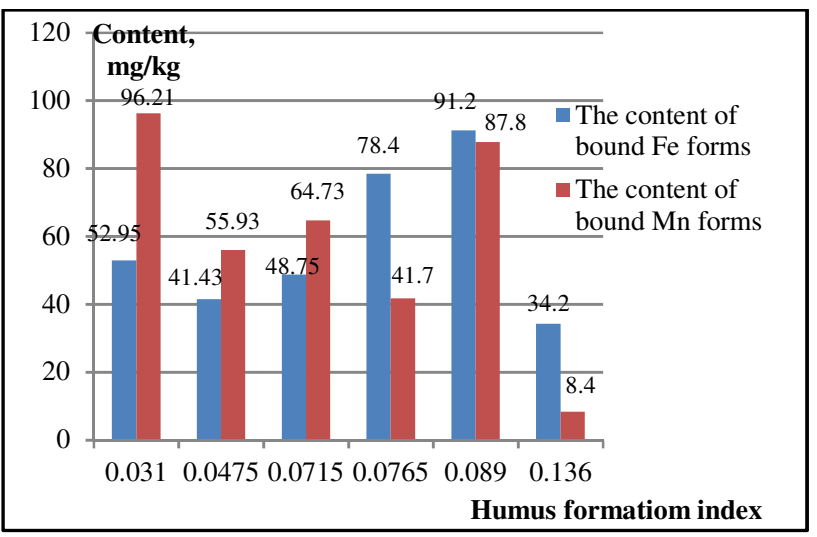

Fig. 2. Dependence of the humus formation index on the content of bound forms of heavy metals.

\section{Discussion}

The results show that the soils have a slightly acidic environment. The value of the total hardness for all extracts is small, which indicates a low content of watersoluble compounds of calcium and magnesium, but there is a correlation: with an increase of hardness, the humus formation index increases. During the analysis, it was found that the content of carbonates and sulfates, as well as water-soluble forms of chromium, is below the detection limit The content of chlorides in all samples is approximately the same, and the content of hydrocarbonates decreases with an increase in the humus formation index. It was found that with an increase in the content of nitrite ions from 3.13 to $15.55 \mathrm{mg} / \mathrm{kg}$, the content of ammonium cations also increases from 6.68 to $12.73 \mathrm{mg} / \mathrm{kg}$.

According to the results, the following dependence can be deduced: with an increase in the content of iron, phosphates, the humus formation index increases, while a decrease in the concentrations of water-soluble forms of manganese and aluminum is observed. This is due to the fact that phosphorus fixes aluminum, reducing its mobility, and an increase in the iron content leads to a decrease in the concentration of mobile forms of manganese. There is also a clear dependence of the humus formation index on the total boron content: the more boron, the higher the humus formation index.

Based on the results, it is also necessary to deduce dependencies: with an increase in the iron content, the humus formation index increases, in the case of manganese, an inverse dependence is observed.

Table 6 shows the data of the dependence of the humus formation index on the total content of various forms of iron and manganese in bound and free forms.

Table 6. Dependence of the humus formation index on the total content of various forms of iron and manganese in bound and free forms

\begin{tabular}{|c|c|c|}
\hline № & $\begin{array}{c}\text { Humus formation } \\
\text { index }\end{array}$ & $\begin{array}{c}\text { Total content of Mn and Fe, } \\
\mathrm{mg} / \mathrm{kg}\end{array}$ \\
\hline 1 & 0.031 & 152.26 \\
\hline 2 & 0.075 & 99.62 \\
\hline 3 & 0.0715 & 115.3 \\
\hline 4 & 0.0765 & 124.32 \\
\hline 5 & 0.089 & 183.21 \\
\hline 6 & 0.136 & 46.81 \\
\hline
\end{tabular}

\section{Conclusions}

Based on the results, the following conclusions can be drawn:

1. Sample preparation of soil samples was performed, aqueous and sulfo-acid extracts were prepared;

2. Soil samples were examined for the content of organic fractions, according to the results obtained, the humus formation index was calculated;

3. With an increase in the concentration of various nitrogen-containing compounds (nitrite, nitrate ions and ammonium cations), the humus formation index increases;

4. With an increase in the content of iron, both watersoluble and bound forms, the humus formation index increases, the same dependence is observed with phosphate ions, while a decrease in the concentrations of manganese (including water-soluble and insoluble forms) and aluminum is observed. This is due to the fact that phosphorus fixes aluminum, reducing its mobility, and an increase in the iron content leads to a decrease in the concentration of mobile forms of manganese. 


\section{References}

1. N.I. Vasilchenko, Bull. AGAU, 6 (2014)

2. A.A. Teuchez, Sci. J. KubGAU, 127 (2017)

3. E.V. Rogozhnikova, U.N. Zborshchuk, Bull. Moscow Univ., 17, 3 (2009)

4. D.S. Orlov, Humic acids, soil, general theory of humification (MGU Publ., 1990)

5. A.E. Probilat, E.I. Voloshin, Trace elem. in med., 18, 3 (2017)

6. A. Ertani, A. Mietto, M. Borinet et al., Water Air Soil Pollut. 228, 190 (2017). DOI: 10.1007/s11270017-3356-y

7. RD 52.24.395-2017, Hardness of water. Methods for performing measurements by the titrimetric method with Trilon B (Rostov-on-Don, 2018)

8. GOST 4245-72, Drinking water. Methods for determination of chloride content (Moscow, 1974)

9. GOST 31957-2012, Water. Methods for determination of alkalinity and mass concentration of carbonates and hydrocarbonates (Moscow, 2014)

10. GOST 31940-2012, Drinking water. Methods for determination of sulfate content (Moscow, 2014)
11. GOST 33045-2014, Water. Methods for the determination of nitrogen-containing substances (Moscow, 2016)

12. PND F 14.1: 2: 4.181-02 (instead of 14.1: 2: 4.2495), Methods for performing the mass concentration of aluminum in samples of natural, drinking and waste water by the fluorometric method using the Fluorat-02 liquid analyzer (Moscow, 2002)

13. PND F 14.1: 2: 4.61-96, Methodology for measuring the mass concentration of manganese in natural and waste waters by the photometric method with ammonium persulfate (Moscow, 2013)

14. PND F 14.1: 2: 4.36-95, Methods for measuring the mass concentration of boron in samples of natural, drinking and waste water by the fluorimetric method on the fluid analyzer "Fluorat-02" (Moscow, 1995)

15. PND F 14.1: 2: 4.112-97, Methodology for measuring the mass concentration of phosphate ions in drinking, natural and waste waters by the photometric method with ammonium molybdate (Moscow, 1997)

16. PND F 14.1: 2: 4.52-96, Methods for measuring the mass concentration of chromium ions in drinking, natural and waste waters by the photometric method with diphenylcarbazide (Moscow, 2016) 